\title{
Seasonal effect on sperm motility characteristics and plasma membrane integrity in boar ejaculate fractions
}

\author{
L. Fraser, K. Filipowicz and W. Kordan
}

Department of Animal Biochemistry \& Biotechnology, University of Warmia and Mazury in Olsztyn, Poland

The quality of boar semen is influenced by many factors, such as age, season, and seminal plasma composition (Xu et al. 1996; Fraser et al. 2003; Koziorowska-Gilun et al. 2011). Among these factors, seasonal variations may be seen as the most noticeable factor that affects boar semen quality (Strzeżek et al. 2000). Moreover, boar seminal plasma, a complex mixture originating in different accessory sex glands, contains a wide variety of components that are implicated in sperm function (Muiño-Blanco et al. 2008; Rodríguez-Martínez et al. 2011). This study aimed to investigate the effects of seasonalrelated variations on motility characteristics and membrane status of spermatozoa originating from different fractions of boar ejaculate.

Ejaculates were collected from five Polish Large White boars. At collections, the ejaculates were split into 3 fractions as follows: approximately $8 \mathrm{ml}$ of the sperm-rich fraction, SRF (F1); the remaining part of the SRF (approximately $2 \mathrm{ml}$ ) and approximately $8 \mathrm{ml}$ of the post-SRF (F2); and the remaining part of the post-SRF (F3). The ejaculates were collected during the autumn-winter (October through March) and spring-summer periods (April through September) periods ( $n=50$, respectively). Vesicular gland and cauda epididymidal fluids were retrieved from animals at the slaughterhouse during the seasonal periods. Sodium dodecyl sulphate polyacrylamide gel electrophoresis (SDS-PAGE) was used to identify the protein profiles of each ejaculate fraction, vesicular gland and cauda epididymidal fluids. Sperm motility characteristics, evaluated with the computer-assisted sperm analysis (CASA) system (HTR-IVOS 12.1, Hamilton Thorne Biosciences, Beverley, MA, USA), included total and progressive motility (TMOT and PMOT, respectively), mean path velocity (VAP), straight line velocity (VSL), curvilinear velocity (VCL), mean amplitude of lateral head displacement (ALH) and beat cross frequency (BCF). The SYBR-14/propidium iodide (PI) assay and hypoosmotic swelling (HOS) test were used to monitor the sperm plasma membrane integrity. Also, the percentage of normal apical ridge (NAR) acrosome was determined and the susceptibility of the sperm membrane lipids to induced lipid peroxidation (LPO) was analyzed by measuring the production of malondialdehyde (MDA). The data were subjected to a mixed factorial design with ANOVA followed by analysis with the Neuman-Keuls post hoc test $(\mathrm{P}<0.05)$.

Even though there were marked variations in the total protein content among the boars, no significant differences were observed between the autumn-winter and spring-summer periods. Seminal plasma of F3 yielded the highest total protein content, which was lowest in F1, regardless of the seasonal periods. SDS-PAGE analysis revealed differences in the protein composition of F1, F2 and F3, and fluids of the vesicular glands and cauda epididymidis during the autumn-winter and spring-summer periods. Electrophoretic analysis of F1 showed similarity in terms of the number of protein bands and their molecular masses to the cauda epididymidal fluid. Furthermore, the protein fractions detected in F2 appeared to originate in the vesicular gland and cauda epididymidal fluids, whereas F3 comprised protein fractions which were predominant in the vesicular gland fluid. When the data were analyzed by three-way ANOVA, there were effects of seasonal periods (autumn-winter $\times$ spring-summer), ejaculate fractions $(\mathrm{F} 1 \times \mathrm{F} 2 \times \mathrm{F} 3)$ and individual boars $(\mathrm{P}<0.05)$. Seasonal periods had a significant effect on TMOT, PMOT, VAP, VSL, VCL and the sperm membrane integrity $(\mathrm{P}<0.05)$. Also, differences in the ejaculate fractions significantly affected $(\mathrm{P}<0.05) \mathrm{VAP}, \mathrm{VCL}$, ALH and BCF. The ejaculate fractions displayed different sperm concentrations, which were highest in F1 and lowest in F3. Table 1 shows the motility characteristics and membrane status of spermatozoa

E-mail: fraser@uwm.edu.pl 
from different ejaculate fractions during the autumn-winter and spring-summer periods. There were no significant differences in sperm TMOT between the seasonal periods ( $P>0.05$ ). Irrespective of the ejaculate fractions, the percentage of progressive motile spermatozoa was significantly higher during the autumn-winter period compared with the spring-summer period $(P<0.05)$. No marked differences in PMOT were observed among the ejaculate fractions either for the autumn-winter period or the spring-summer period. It was observed that the proportions of spermatozoa showing rapid movements were significantly higher during the autumn-winter period $(P<0.05)$, particularly in F1. There were wide seasonal variations in the analyzed velocity parameters, such as VAP, VSL and $\mathrm{VCL}$, being significantly higher during the autumn-winter period $(\mathrm{P}<0.05)$. There were no marked differences among F1, F2 and F3 during the autumn-winter period or spring-summer period. It was found that the values of ALH and BCF did not differ between the seasonal periods either for F1, F2 or F3. The values of $\mathrm{ALH}(\mu \mathrm{m})$ and $\mathrm{BCF}(\mathrm{Hz})$ ranged from 6.7 to $7.0 \mu \mathrm{m}( \pm 0.3)$ and $31.3 \mathrm{to} 32.8 \mathrm{~Hz}$ $( \pm 0.7)$ during the autumn-winter period, respectively, and 6.3 to $6.8( \pm 0.2)$ and 31.8 to $33.1 \mathrm{~Hz}( \pm$ 0.8) during the spring-summer period, respectively. Ejaculates harvested during the autumn-winter period exhibited higher proportions of SYBR-14-positive (SYBR-14+) and HOS-positive (HOS +) spermatozoa. Such changes were associated with higher percentages of NAR acrosome and reduced LPO susceptibility in spermatozoa.

Table 1. Characteristics of spermatozoa from different ejaculate fractions during the seasonal periods. Within column values with different letters are significant at $P<0.05$ (means $\pm S E M$ ).

\begin{tabular}{|c|c|c|c|c|c|c|c|c|c|}
\hline \multirow{2}{*}{\multicolumn{2}{|c|}{$\begin{array}{l}\text { Seasonal } \\
\text { periods }\end{array}$}} & \multirow[t]{2}{*}{$\begin{array}{c}\text { PMOT } \\
(\%)\end{array}$} & \multicolumn{3}{|c|}{ Velocity parameters $(\mu \mathrm{m} / \mathrm{sec})$} & \multicolumn{2}{|c|}{$\begin{array}{c}\text { Plasma membrane } \\
\text { integrity (\%) }\end{array}$} & \multirow[t]{2}{*}{$\begin{array}{c}\text { NAR } \\
(\%)\end{array}$} & \multirow{2}{*}{$\begin{array}{c}\text { LPO } \\
(\mathrm{nmol} \\
\left.\mathrm{MDA} / 10^{8} \mathrm{spz} .\right)\end{array}$} \\
\hline & & & VAP & VSL & $V C L$ & SYBR-14+ & HOS + & & \\
\hline \multirow{3}{*}{$\begin{array}{l}\text { Autumn- } \\
\text { Winter } \\
(n=50)\end{array}$} & $\mathrm{F} 1$ & $\begin{array}{c}63.1 \\
\pm 1.4^{\mathrm{a}}\end{array}$ & $\begin{array}{l}81.6 \\
\pm 1.8^{a}\end{array}$ & $\begin{array}{l}62.1 \\
\pm 1.4^{\mathrm{a}}\end{array}$ & $\begin{array}{l}148.8 \\
\pm \quad 4.2^{\mathrm{a}}\end{array}$ & $\begin{array}{c}89.3 \\
\pm 1.4^{\mathrm{a}}\end{array}$ & $\begin{array}{c}91.6 \\
\pm 1.0^{\mathrm{a}}\end{array}$ & $\begin{array}{r}92.9 \\
\pm 0.7^{a}\end{array}$ & $\begin{array}{c}21.9 \\
\pm 1.3^{\mathrm{a}}\end{array}$ \\
\hline & $\mathrm{F} 2$ & $\begin{array}{l}62.7 \\
\pm 1.8^{\mathrm{a}}\end{array}$ & $\begin{array}{l}76.9 \\
\pm 2.1^{\mathrm{a}}\end{array}$ & $\begin{array}{c}59.6 \\
\pm 2.0^{\mathrm{a}}\end{array}$ & $\begin{array}{l}139.6 \\
\pm 4.3^{\mathrm{a}}\end{array}$ & $\begin{array}{l}87.7 \\
\pm 0.9^{\mathrm{ac}}\end{array}$ & $\begin{array}{c}90.3 \\
\pm 1.1^{\mathrm{a}}\end{array}$ & $\begin{array}{l}91.5 \\
\pm 0.8^{\mathrm{ab}}\end{array}$ & $\begin{array}{l}22.3 \\
\pm 1.2^{\mathrm{ac}}\end{array}$ \\
\hline & F3 & $\begin{array}{l}61.6 \\
\pm 1.9^{a}\end{array}$ & $\begin{array}{l}77.8 \\
\pm 1.7^{\mathrm{a}}\end{array}$ & $\begin{array}{c}58.9 \\
\pm 1.6^{\mathrm{ac}}\end{array}$ & $\begin{array}{l}137.6 \\
\pm 3.8^{\mathrm{a}}\end{array}$ & $\begin{array}{l}87.9 \\
\pm 0.8^{\mathrm{ac}}\end{array}$ & $\begin{array}{c}88.8 \\
\pm 1.2^{\text {ac }}\end{array}$ & $\begin{array}{l}92.6 \\
\pm 1.0^{\mathrm{a}}\end{array}$ & $\begin{array}{l}23.6 \\
\pm 1.1^{\mathrm{ac}}\end{array}$ \\
\hline \multirow{3}{*}{$\begin{array}{l}\text { Spring- } \\
\text { Summer } \\
(n=50)\end{array}$} & $\mathrm{F} 1$ & $\begin{array}{l}49.6 \\
\pm 2.5^{b}\end{array}$ & $\begin{array}{l}69.1 \\
\pm 2.1^{b}\end{array}$ & $\begin{array}{l}51.9 \\
\pm 1.7^{\mathrm{bc}}\end{array}$ & $\begin{array}{l}126.9 \\
\pm 3.5^{b}\end{array}$ & $\begin{array}{l}84.5 \\
\pm 1.1^{\mathrm{bc}}\end{array}$ & $\begin{array}{l}85.7 \\
\pm 0.6^{b c}\end{array}$ & $\begin{array}{l}90.5 \\
\pm 0.6^{\mathbf{b}}\end{array}$ & $\begin{array}{l}25.9 \\
\pm 0.8^{\mathrm{bc}}\end{array}$ \\
\hline & $\mathrm{F} 2$ & $\begin{array}{l}51.9 \\
\pm 2.4^{\mathrm{b}}\end{array}$ & $\begin{array}{r}64.4 \\
+1.9^{b}\end{array}$ & $\begin{array}{l}49.5 \\
\pm 1.5^{b}\end{array}$ & $\begin{array}{l}123.6 \\
\pm 3.1^{\mathrm{b}}\end{array}$ & $\begin{array}{c}83.8 \\
\pm 1.6^{b}\end{array}$ & $\begin{array}{r}86.6 \\
\pm 1.1^{b c}\end{array}$ & $\begin{array}{c}91.1 \\
\pm 1.1^{a b}\end{array}$ & $\begin{array}{c}25.7 \\
\pm 1.2^{b c}\end{array}$ \\
\hline & F3 & $\begin{array}{c}52.5 \\
\pm 2.7^{\mathrm{b}}\end{array}$ & $\begin{array}{c}66.8 \\
\pm 2.0^{b}\end{array}$ & $\begin{array}{c}51.5 \\
\pm 1.6^{b}\end{array}$ & $\begin{array}{r}127.7 \\
\pm 2.9^{b}\end{array}$ & $\begin{array}{c}82.2 \\
\pm 1.2^{b}\end{array}$ & $\begin{array}{c}84.5 \\
\pm 0.5^{\mathbf{b}}\end{array}$ & $\begin{array}{c}89.9 \\
\pm 1.0^{\mathbf{b}}\end{array}$ & $\begin{array}{c}27.3 \\
\pm 0.9^{b}\end{array}$ \\
\hline
\end{tabular}

It can be suggested that changes in sperm motility characteristics and membrane status reflect differences in the protective components of the seminal plasma, mainly protein substances, originating in the various accessory sex glands. The findings of this study indicated that variations in boar seminal plasma proteome during the seasonal periods affected sperm function. A more in-depth study of the seasonal effect on the seminal plasma proteome and its association with boar fertility warrants further investigation.

This study was supported by funds from UWM in Olsztyn (No. 0103.0803).

\section{References}

Fraser L, Gorszczaruk K, Lecewicz M \& Strzeżek J 2003. Age-related changes and seasonal variation in boar sperm metabolism during liquid storage at $5^{\circ}$ and $16^{\circ} \mathrm{C}$. J Anim Feed Sci 12 805-813.

Koziorowska-Gilun M, Koziorowski M, Strzeżek J \& Fraser L 2011. Seasonal changes in antioxidant defence systems in seminal plasma and fluids of boar reproductive tract. Reproductive Biology 11 37-47.

Muiño-Blanco T, Pérez-Pé R \& Cebrián-Pérez JA 2008. Seminal plasma proteins and sperm resistance to stress.
Reprod Domest Anim 43 (Suppl. 4) 18-31.

Rodríguez-Martínez H, Kvist U, Ernerudh J, Sanz L \& Calvete J 2011. Seminal plasma proteins: What role do they play? Am J Reprod Immunol 66 (Suppl. 1) 11-22.

Strzeżek J, Fraser L, Demianowicz W, Kordan W, Wysocki P \& Hołody D 2000. Effect of depletion tests (DT) on the composition of boar semen. Theriogenology 54 949-963.

Xu X, Ding J, Seth PC, Harbison DS \& Foxcroft GR 1996. In vitro fertilization of in vitro matured pig oocytes: effects of boar and ejaculate fraction. Theriogenology 45 745-755. 